\title{
Výběrové zaměrení pozornosti u studentů učitelství a povaha jejich interpretací
}

\author{
Lenka Pavlasová, Jana Stará, Naďa Vondrová, \\ MagdalÉNa Novotná, Jarmila Robová, KLÁra UličNá
}

\begin{abstract}
Abstrakt: Profesni vidèní je dìležitým spojnikem mezi profesním vèdèním a profesním jednáním. Článek predstavuje výsledky výzkumu profesniho vidèni studentù učitelství jednak pro 2. a 3. stupeñ a jednak pro 1. stupeň ZŠ, a to na počátku studia obecné didaktiky i didaktik oborových. Pomocí analýzy pisemných reflexí $(n=211)$ na videu zhlédnuté vyučovaci hodiny zkoumá výbèrové zamèrení pozornosti a to, do jaké miry a jak studenti zaznamenané jevy popisuji, hodnotí a interpretuji. Významové jednotky byly kódovány kategoriálním systémem podle Sherinové a van Esové (2009) a modifikovaným systémem podle Stockerové (2008). Výroky kódované jako teoretizace, predikce a alterace byly analyzovány kvalitativně s cilem postihnout jejich povahu. Voblasti výbèrového zaměreni pozornosti výzkum potvrdil některé výsledky ziskané u studentů učitelstvi matematiky v prèedchozich výzkumech, poukázal však i na rozdily. Studenti učitelstvi 1. stupnè si vice všimaji žáka, zatímco výroky studentů učitelstvi 2. a 3. stupně jsou zamèreny stejnou mèrou na učitele i žáka. Studenti obou skupin komentuji spiše obecné pedagogické jevy na úkor oborových a oborově didaktických, velmi málo interpretují (studenti učitelství 1. stupné ještè ménè než studenti druhé skupiny) a jejich poznámky mají spiše obecný charakter. Vjejich komentárích je patrný di̛raz na žákivv aktivni prístup $k$ učeni. Zjišténé výsledky mohou prispět $k$ inovacím obsahu didaktických disciplin v učitelské prípravě a $k$ rozvoji spolupráce mezi didaktiky.
\end{abstract}

Kličová slova: profesni vidèní, všimání si, student učitelství, interpretace vidèného, prǐpravné vzděláváni učitelì.

Př́pravu učitelů lze vidět jako cestu $\mathrm{k}$ profesionalitě učitele a jako taková by měla ovlivňovat všechny tři její dimenze identifikované Minaříkovou a Janíkem (2012), a sice profesní vidění, profesní vědění a profesní jednání. Profesní vidění je podle nich důležitým spojníkem mezi profesním věděním a jednáním. Zaměření pozornosti je klíčové pro rozvoj profesních dovedností učitelů. Teprve o tom, čeho si všimneme, můžeme uvažovat a ve výuce s tím efektivně pracovat. V článku se zaměřujeme na zmapování profesního vidění jako specifického způsobu vidění jevů prítomných ve vyučovacích hodinách u budoucích učitelů 1. a 2. stupně na začátku jejich oborově didaktické př́pravy. Jsme přitom vedeni snahou zaplnit bílá místa v českém výzkumu ve třech aspektech. 
První se týká samotného profesního vidění, které je zkoumáno především u učitelů a studentů učitelství matematiky a príírodovědných předmětů, v českém prostředí také anglického jazyka. Pokud je nám známo, chybí poznatky o profesním vidění studentů učitelství umělecko-výchovných a sociálně-humanitních předmětů a pouze ojedinělé studie se věnují zkoumání profesního vidění učitelů či studentů učitelství 1. stupně základní školy. Podle Janíka et al. (2016) je žádoucí orientovat pedagogický výzkum na komparativní zkoumání profesního vidění u studentů učitelství či učitelů různých předmětů, čímž je možné získat informace o jejich vnímání profesních situací, napomoci ke zlepšení jejich vzájemné komunikace, a přispět tak $\mathrm{k}$ budování transdidaktické teorie a objasnění doménové specifičnosti profesního vidění.

Druhý aspekt je spojen se zkoumáním studentů učitelství $\mathrm{v}$ různých etapách jejich profesní př́pravy. Podle Svatoše (2013) je malá pozornost věnována zkoumání studentů učitelství na začátku profesní př́ípravy. Protože profesní vidění není jen kognitivní schopnost, ale zahrnuje i sociální dovednosti a citlivost (Janík et al., 2016), může být profesní vidění u studentů učitelství před zahájením obecné i oborově didaktické př́pravy různou měrou rozvinuté a výběrově zaměřené. Bližší poznání struktury profesního (slovy Janíka et al., 2014, spíše před-profesního) vidění studentů může přispět $\mathrm{k}$ lepšímu koncipování jejich profesní přípravy.
Konečně třetí aspekt souvisí s odlišnou prrípravou učitelů 1 . stupně a 2 . a 3 . stupně a s rozdíly mezi studenty, kteř́ tyto obory studují (odlišují se nap̌r. v profesní aspiraci studentů obou stupňů; Urbánek, 2011).

\section{TEORETICKÁ VÝCHODISKA}

\section{A STAV POZNÁNÍ PROBLEMATIKY}

\subsection{Profesní vidění}

Jednou z dovedností, kterou si mají (budoucí) učitelé osvojit, je specifický způsob vidění jevů prítomných ve vyučovacích hodinách, uchopený pojmem profesní vidění (professional vision, český termín používáme ve shodě s Minaříkovou a Janíkem, 2012). Tento pojem představily v pedagogickém výzkumu Sherinová a van Esová (2009). Podle nich se skládá ze dvou znalostně založených dílčích procesů, a sice výběrového zaměření pozornosti $(s e-$ lective attention, tedy všímání si toho, co $\mathrm{v}$ dané situaci považuje učitel za podstatné) ${ }^{1}$ a uvažování založeného na znalostech (knowledge-based reasoning, tedy uvažování o tom, čeho si učitel všiml ve světle svých znalostí a zkušeností). U druhého procesu je možné rozlišit kvalitativně odlišné způsoby, jak o všimnutých jevech učitelé uvažují; může jít o pouhý popis či nezdůvodněné hodnocení na jedné straně či o vysvětlení jevu až s oporou o teorii na straně druhé. Minař́íková a Janík (2012, s. 197) vymezují celkem šest dílčích procesů uvažování založeného na znalostech.

\footnotetext{
${ }^{1}$ Pro první z procesů se v literatuře užívá obou termínů: všímání si i selektivní zaměření pozornosti. Jedná se „o percepční procesy, které jsou znalostně založeny a umožňují identifikovat jevy, jež jsou z profesního hlediska podstatné pro úspěch či efektivnost jednání učitele“ (Janík et al., 2014, s. 156).
} 
Všímání si je věnována značná výzkumná pozornost. K jejímu zkoumání se zpravidla využívají reflektivní úkoly, kdy účastníci zhlédnou videozáznam hodiny a následně ho komentují písemně (např. Blomberg, Stürmer \& Seidel, 2011; Santagata \& Guarino, 2011), při interview (napřr. Mitchell \& Marin, 2015) či při společných diskusích (např. Sherin $\&$ van Es, 2009). V posledně uvedeném př́padě se různé aspekty profesního vidění často popisují u skupiny jako celku, čímž se ztratí vnitřní variabilita. Pro analýzu dat se využívají kategoriální systémy, které zachycují různé aspekty hodiny. Nejvíce rozšsirirený je systém Sherinové a van Esové (2009), který vymezuje čtyřri dimenze: aktér, téma, př́stup a míra konkrétnosti (podrobněji viz 2.3.1). $V$ dalších výzkumech je různě modifikován jinými výzkumníky (např. Stockero, 2008; Mitchell \& Marin, 2015).

Zejména v zahraničí je profesnímu vidění věnována velká pozornost, a to zpravidla (budoucím) učitelům matematiky či př́rodovědných předmětů. U nás existují spíse ojedinělé studie u studentů učitelství matematiky, anglického jazyka či mateřských škol (např. Simpson, Vondrová \& Žalská, 2017; Stehlíková, 2010; Vondrová \& Žalská, 2015; Minaříková, 2014; Minaříková et al., 2015; Syslová, 2016; Uličná, 2017). Podstatná část výzkumů profesního vidění je věnována problematice jeho rozvoje formou různých intervencí zpravidla založených na využití videa (např. Minaříková, 2014; Mitchell \& Marin, 2015; Santagata \& Guarino, 2011). Ty jsou pro naše účely relevantní svými výsledky u studentů na začátku intervence; pokud je nám známo, výzkumy mapující profesní vidění u studentů učitelství na začátku jejich profesní prrípravy prakticky neexistují.

Výzkumy se shodují v tom, že studenti učitelství matematiky zaměřují pozornost spíše na obecné didaktické jevy na úkor obsahu a jeho výuky a na učitele a jeho činnost na úkor všímání si žáků (Santagata, Zannoni \& Stigler, 2007; Michtell \& Marin, 2015; Stockero, Rupnow \& Pascoe, 2017). Simpson, Vondrová a Žalská (2017) potvrzují zaměření na učitele, ovšem odlišují se v zaměření na obsah jejich studenti učitelství komentovali více matematický obsah než obecné pedagogické jevy. Dále se ukazuje, že komentáre studentů jsou spiše obecného charakteru bez vazby na události v hodině, kterou zhlédli (Simpson et al., 2017), a spíše pozitivního charakteru (Santagata et al., 2007). Výše uvedené studie se také shodují v tom, že studenti spíše popisují a hodnotí a velmi málo tyto jevy interpretují. Podobné výsledky však chybí pro studenty učitelství jiných předmětů než matematiky (pokud existují, tak pro studenty učitelství v jiné etapě jejich prrípravy než v našem př́padě). U budoucích učitelů 1 . stupně potvrzuje zaměření na učitele i studie Santagatové a Guarinové (2011), ovšem opět u hodiny matematiky.

Profesní vidění se zdá být specifickou schopností, která závisí na konkrétním zaměrení zkoumané osoby. Např́iklad Steffensky et al. (2015) zkoumali všímání si řízení třídy (pedagogicko-psychologických aspektů výuky nesouvisejících s jejím obsahem) a podpory učení žáků (aspektu zaměřeného na obsah) ve videoukázkách 
předmětu prvouka na 1 . stupni u studentů učitelství a učitelů $\mathrm{v}$ praxi. Respondenti z obou skupin, kteří absolvovali předchozí vzdělání orientované na obor (př́rodní vědy), vykazovali lepší výsledky v profesním vidění podpory učení žáků oproti řizení tř́ídy v porovnání s účastníky, kteří tyto zkušenosti s oborem neměli.

\subsection{Studenti učitelství 1. a 2. stupně}

Rozdíly mezi studenty učitelství obou stupňủ škol v různých ohledech potvrzuje i výzkum, který shrnuje Urbánek (2011). Podle něj se autoři shodují, že „motivace $\mathrm{k}$ práci učitele je na počátku i v průběhu studia kromě jiného diferencována podle oborů, přičemž významně silnější je vždy u studentů učitelství 1 . stupně a váže se také daleko výrazněji k práci $s$ dítětem“ (s. 278). U studentů učitelství 1. stupně byly nalezeny prríznivější hodnoty $\mathrm{v}$ oblastech vztahu ke sledovanému oboru, $\mathrm{k}$ fakultě i budoucí profesi (Kučera et al., 1994). Podle této studie směřuje oddanost („,commitment“) k budoucí profesi, která je formulována na pólech učitel-odborník, u studentů učitelství 1 . stupně daleko více k univerzálnosti, ke škole a k dítěti, zatímco u studentů učitelství 2 . stupně $\mathrm{k}$ seberealizaci prostřednictvím oboru studia.

Jedním z důvodů může být odlišný charakter př́ípravy učitelů 1 . stupně. Ta je (nejen) na Pedagogické fakultě Univerzity Karlovy orientována více směrem $\mathrm{k}$ pedagogickým a psychologickým disciplínám a méně $\mathrm{k}$ oboru, než je tomu u oborových studentů. Učitelé 1 . stupně nemohou nut- ně jít do tak velké hloubky oboru a současně musejí zvládnout základy více oborů. Urbánek (2011) zdůrazňuje ještě druhý důvod, a sice odlišně specifické osobnostní profily studentů obou stupňů učitelství. V oblasti profesního vidění bychom tedy mohli očekávat větší zaměření na žáka a obecnou didaktiku či pedagogiku u studentů 1. stupně a na obor studia u učitelství 2. stupně. Toto očekávání lze do jisté míry podeprrít i výsledky výzkumu přesvědčení učitelů, $v$ nichž autoři zjistili, že učitelé 1 . stupně mají statisticky významně pozitivnější vztah ke konstruktivistické výuce a $\mathrm{k}$ pedocentrickému př́stupu (Straková et al., 2014). První rozdíl se ukázal i mezi studenty učitelství, i když zde nebyl vzorek reprezentativní.

Žádný výzkum profesního vidění, pokud můžeme soudit, se nezaměřuje na oba typy studentů učitelství zároveň. Výzkum (Blomberg et al., 2011) je výjimečný v tom, že porovnává profesní vidění u studentů učitelství různých oborů, kteří se dívali na úryvky z hodin z různých předmětů. Rozdíly, které se při tom objevily, přisuzují jednak možnosti, že profesní vidění je doménově specifické, a jednak hypotéze, že různé obory přitahují různě zaměřené studenty s různými dispozicemi $\mathrm{k}$ všímání si. Nezaměřují se sice na rozdíly mezi studenty učitelství různých stupňů škol, ovšem upozorňují na možnou souvislost toho, jaký obor si studenti vybírají a čeho a jak si v hodině všímají.

$\mathrm{V}$ článku zodpovídáme dvě výzkumné otázky, které vyplývají z výše řečeného a týkají se obou procesů profesního vidění: jak výběrového zaměření pozornosti, 
tak uvažování založeného na znalostech. První otázka cílí zejména na první proces $s$ přesahem do druhého (v oblasti prístupu $\mathrm{k}$ viděnému) a druhá otázka se týká druhého procesu.

1. Liší se reflexe na videu zhlédnuté vyučovací hodiny u studentů učitelství 1. a 2. stupně z hlediska výběrového zaměření jejich pozornosti a př́stupu $\mathrm{k}$ viděnému, a pokud ano, tak v čem?

2. Jaká je povaha interpretací, tedy které všimnuté jevy studenti interpretují a jak? Jsou rozdíly mezi studenty učitelství 1. a 2. stupně?

\section{Metodologie}

\section{1 Účastníci výzkumu}

Výzkumu se zúčastnili studenti, kteří neabsolvovali obecnou ani oborovou didaktiku, můžeme je tedy při jisté míre zjednodušení nazývat studenty na počátku učitelského vzdělávání. Byli to (a) studenti 1. ročníků navazujícího magisterského studia učitelství anglického jazyka, biologie, matematiky a výtvarné výchovy pro 2. a 3. stupeň školy (zde „studenti učitelství 2. stupně“), kteří předtím absolvovali trŕleté bakalářské studium zaměřené na obor, a (b) studenti 2. či 3. ročníků neděleného pětiletého studia učitelství pro 1. stupeň, kteří $\mathrm{v}$ předchozích letech na fakultě neabsolvovali žádné didaktické předměty (tab. 1). Ovšem, na rozdíl od studentů učitelství 2. stupně, jejich studium bylo zaměřeno více směrem $\mathrm{k}$ pedagogice a základům různých oborů. Konkrétně zmíníme Úvodní pedagogický kurz s praxí, kdy studenti hospitují na základní škole, provádí pozorování a následně $\mathrm{v}$ semináŕi s učitelem $\mathrm{z}$ fakulty reflektují pozorované skutečnosti. Zkušenosti z tohoto předmětu jsou využity v předmětech Osobnostní a sociální výchova a Ontogenetická psychologie, které také měli studenti v době zadávání reflexe absolvovány, stejně jako Dějiny pedagogiky, Úvod do pedagogiky a Psychologie osobnosti. Většina studentů 2. stupně absolvovala $\mathrm{v}$ bakalářském studiu Základy psychologie, Psychologii dítěte školního věku, Sociální pedagogiku a Úvod do pedagogiky. Ovšem vše formou přednášek; jednalo se tedy o teoretické kurzy bez praktických a reflektivních aktivit.

Tab. 1. Počet analyzovaných reflexí po oborech

\begin{tabular}{|c|c|c|c|}
\hline Učitelství 1. stupně & Počet & Učitelství 2. stupně & Počet \\
\hline Anglický jazyk AJ1 & 11 & Anglický jazyk AJ2 & 34 \\
\hline Matematika MA1 & 28 & Biologie BI2 & 26 \\
\hline Vlastivěda VL1 & 36 & Matematika MFF & 21 \\
\hline \multirow[t]{3}{*}{ Výtvarná výchova VV1 } & 21 & Matematika MA2 & 20 \\
\hline & & Výtvarná výchova VV2 & 14 \\
\hline & 96 & & 115 \\
\hline
\end{tabular}


Výzkumný vzorek byl vytvořen na základě dostupnosti. $V$ př́padě studentů BI2, VV2, MA2 a MFF (zkratky viz tab. 1) se jednalo o všechny studenty ročníku, u studentů AJ1 šlo o všechny studenty specializace AJ. U učitelství 1. stupně byli osloveni všichni studenti před výukou obecné didaktiky s tím, aby si vybrali $\mathrm{k}$ reflexi hodinu matematiky, vlastivědy nebo výtvarné výchovy. Z 95 studentů v ročníku alespoň jednu reflexi odevzdalo 79 studentů a čtyři studenti odevzdali více než jednu reflexi. Skupina MFF jsou studenti z Matematicko-fyzikální fakulty Univerzity Karlovy, ostatní jsou z Pedagogické fakulty stejné univerzity. $Z$ celkového počtu 211 reflexí bylo 37 psáno muži $(17,5 \%)$ a 174 ženami $(82,5 \%)$, což odpovídá skladbě studentů na fakultè.

\subsection{Výzkumný nástroj a sběr dat}

Ve výzkumu byla využita videa celých vyučovacích hodin $\mathrm{z}$ běžných tříd českých škol, které byly vybrány s ohledem na př́tomnost didakticky nosných jevů. Nešlo však primárně o ukázky dobré praxe. V každé hodině se objevovalo zprostředkování nového učiva žákům. Jednalo se o autentickou výuku, jejíž obsah je pro pozorovatele dobře srozumitelný, zahrnuje jasně identifikovatelný začátek a konec, znalost dalšího kontextu tedy není nutná. Hodina vlastivědy (úkol pro studenty VL1) se týkala plýtvání potravinami. Žáci byli vedeni $\mathrm{k}$ analýze důsledků plýtvání a $\mathrm{k}$ přemýšlení nad možnostmi řešení tohoto globálního problému. V hodině byla použita dialogická, názorně-demonstrač- ní a problémová metoda a žáci pracovali hromadně či ve skupinách. Tématem hodiny biologie (úkol pro studenty BI2) byla morfologie a životní prostředí měkkýšson. Žáci 2. ročníku čtyřletého gymnázia nejprve ve skupinách vyhledávali informace $\mathrm{z}$ textu $\mathrm{v}$ učebnici a poté prezentovali tyto informace spolužákủm a ukazovali důležité pojmy na prírodninách. Studenti VV1 a VV2 shlédli videozáznam hodiny výtvarné výchovy pořízený v 7 . ročníku $Z$ Š s rozšírenou výukou výtvarné výchovy. Hodina byla úvodem do projektu zaměřeného na portrétní tvorbu pomocí různých médií a identitu člověka. Videozáznam zachycuje úvod projektu, uvažování nad tématem tvár člověka a prrípravu fotografického portrétu. Studenti učitelství anglického jazyka (AJ1 a AJ2) zhlédli výuku anglického jazyka v 8. ročníku základní školy s rozšířenou výukou cizích jazyků. Hodina je zaměřena na výuku nové gramatiky, konkrétně vztažných zájmen, a obsahuje různorodé aktivity. Studenti učitelství matematiky (MA2 a MFF) reflektovali hodinu matematiky, při které žáci nejdříve opakovali učivo formou různých aktivit a následně sami odvozovali Thaletovu větu na základě manipulace s pravítkem. Studenti MA1 komentovali hodinu, $v$ níž žáci manipulovali $s$ geodeskou a provázkem při aktivitách vedoucích $\mathrm{k}$ lepšímu porozumění geometrickým objektům (pravoúhelníkům a trojúhelníkům).

Studenti dostali následující úkol: „Na video se můžete podívat, kolikrát budete chtít. Napište o tomto videu reflexi; rozsah není stanoven. Napište, co vás zaujalo, co je podle vás důležité. Nebojte se 
psát své názory, neexistuje žádná správná odpověd'. Nebudete na základě tohoto textu nijak hodnoceni. Snažte se, prosím, psát celými větami, ne jen heslovitě." Studenti pracovali doma a reflexe odevzdali v elektronické podobě.

\subsection{Analýza dat}

Pro analýzu dat byla zvolena kombinace kvantitativní a kvalitativní metodologie. Písemné reflexe studentů byly rozděleny na významové jednotky. Zpravidla se jednalo o celou větu tvořící kompletní informaci, někde část souvětí, pokud $\mathrm{v}$ něm došlo ke změně zaměření (např. první část věty se týkala učitele a druhá žáka). Př́klady jednotek jsou uvedeny níže. Získané analytické jednotky byly kódovány pomocí dvou kategoriálních systémů.

\subsubsection{Výběrové zaměření pozornosti}

$\mathrm{V}$ první fázi byly reflexe zpracovány kategoriálním systémem podle Sherinové a van Esové (2009). Jednak se jedná o široce rozšířený systém, který umožní výsledky komparovat s jinými výzkumy, a jednak byl dosud využíván, pokud je nám známo, jen pro reflexe hodin matematiky. Zajímalo nás, jak bude použitelný $\mathrm{v}$ jiných předmětech.

Každá jednotka analýzy $(n=5544)$ byla kódována jednou kategorií z každé ze čtyř oblastí (tab. 2). Názvy jednotlivých kategorií vystihují jejich podstatu. Vysvětlení si zaslouží snad jen dvě: do kategorie Pozorovatel videa byly řazeny promluvy, kde student popisuje, co by dělal na místě učitele, a do kategorie Tvůrce kurikula spadaly promluvy týkající se tvůrců vzdělávacích plánů, scénárù hodiny, učebnic a výukových pomůcek.

Badatelky (autorky článku) se opakovaně setkávaly, ladily způsob kódování u několika reflexí a upřesňovaly kódovací manuál původně připravený pomocí prací Sherinové a van Esové. Každou reflexi kódovaly tři badatelky a následně bylo pro každou jednotku učiněno rozhodnutí. Pokud došlo ke shodě u dvou či tř́ kódů, byl vybrán tento kód. Pokud byla nějaká jednotka kódována třikrát jiným kódem (což se stávalo $\mathrm{v}$ jednotlivých kategoriích jen v malém počtu prípadů - od $0 \%$ do $9 \%$,

Tab. 2. Přehled oblastí a kategorií pro kódování výroků (Sherin \& van Es, 2009)

\begin{tabular}{|l|l|l|l|}
\hline $\begin{array}{l}\text { Aktér (Koho/čeho } \\
\text { se jednotka týká?) }\end{array}$ & $\begin{array}{l}\text { Téma (Co je tématem } \\
\text { jednotky?) }\end{array}$ & $\begin{array}{l}\text { Prístup (Jaká je } \\
\text { povaha jednotky?) }\end{array}$ & $\begin{array}{l}\text { Míra konkrétnosti (Týkáa } \\
\text { se jednotka konkrétní udá- } \\
\text { losti, nebo je spíse obecná?) }\end{array}$ \\
\hline Učitel & Obor a oborová didaktika & Popis & Konkrétní \\
\hline Žák & $\begin{array}{l}\text { Pedagogika a obecná } \\
\text { didaktika }\end{array}$ & Hodnocení & Obecný \\
\hline Pozorovatel videa & Klima tř́dy & Intepretace & \\
\hline Tvůrce kurikula & Řízení tř́dy & Jiné & \\
\hline Jiné & Jiné & & \\
\hline
\end{tabular}


medián 1,6 \%), pak se trojice kódujících na výběru kódů dohodla. Pŕíkladem jednotky je "Líbilo se mi, že paní učitelka mluvila celou hodinu anglicky." (Učitel, Obor a oborová didaktika, Hodnocení, Obecný) nebo „Žáci si veškeré informace dokázali vyhledat a doplnit sami." (Žák, Pedagogika a obecná didaktika, Popis, Obecný). Tímto způsobem bylo získáno procentuální zastoupení jednotlivých typů výroků u všech reflexí, čímž jsme získali proměnné odpovídající dané kategorii.

\subsubsection{Povaha interpretací}

Výše uvedený kategoriální systém neumožňuje odlišit nuance charakteru výroků v oblasti Př́stup, např. není možné odlišit „laické“ vysvětlení od vysvětlení opřeného o teorii (ve výše uvedeném kategoriálním systému je obé kódováno jako Interpretace). Byly vybrány jen jednotky označené Interpretace $(\mathrm{n}=847)$ a ty byly zakódovány podle systému inspirovaného prací Stockerové (2008) a obsahujícího čtyři kategorie. Do kategorie Vysvětlení byly zařazeny jednotky obsahující „laické“ vysvětlení toho, co bylo na videu, nebo vysvětlení opřené o vlastní zkušenost jako žáka či učitele. Teoretizace znamená, že pozorovatel viděné vysvětluje $s$ oporou o teorii, snaží se o generalizaci či vyjádření oborově didaktického principu. Termíny označující prítomnost Teoretizace byly napr. kritické myšlení, konstruktivistická výuka, induktivní výuka, motivace aj. Jednotka v kategorii Alterace obsahuje návrh, co udělat jinak. Mezi Predikce patří jednotky, v nichž pozorovatel zvažuje jev pozorovaný $\mathrm{v}$ hodině vzhledem $\mathrm{k}$ budoucnosti (např. „žáci si to budou lépe pamatovat"). Každá jednotka mohla být pruriřazena do více kategorií. Jednotky byly kódovány dvěma členkami týmu, kdy každá zakódovala náhodně vybranou polovinu výroků a druhá provedla poté kontrolu a navrhla korekce. Ty byly prodiskutovány a bylo přijato konečné rozhodnutí.

Abychom získaly odpověd' na druhou výzkumnou otázku, podrobily jsme výroky kódované jako Teoretizace, Predikce a Alterace kvalitativní analýze technikami založenými na zakotvené teorii (Strauss \& Corbinová, 1999). Při otevřeném kódování byly přiřazeny jednotkám kódy vystihující jejich povahu nejdříve ad hoc a posléze byly kódy přejmenovány, precizovány a slučovány tak, aby vznikla logická struktura. Některé významové jednotky se překrývaly, jeden výrok mohl být tedy označen více kódy. Postupně vznikly podkategorie, jejichž část ukazuje tab. 4. Analýzu prováděla dvojice badatelek způsobem popsaným $\mathrm{v}$ předchozím odstavci. Tím vznikl společný kategoriální systém, který byl použit pro organizaci dat a tvorbu analytického př́běhu (Švaříček \& Šed'ová, 2007). Nakonec byla provedena obsahová analýza s cílem odhalit povahu zobecnění, alterací a predikcí.

\section{VÝSLEDKY}

\subsection{Výběrové zaměření pozornosti studenti̊ a postoj $k$ viděnému}

Relativní četnosti zařazení jednotek do kategorií jsou uvedeny v tab. 3 (vzhle- 
dem $\mathrm{k}$ rozsahu článku nelze uvést výsledky pro všechny skupiny studentů zvlášt). Studenti různých skupin neviděli stejnou vyučovací hodinu, proto nebylo provedeno vyhodnocení statistické významnosti rozdílů. Počet respondentů ovšem považujeme za dostatečně vysoký, abychom mohli učinit některé věcné závěry o povaze výběrově zaměřené pozornosti studentů obou skupin.
Reflexe studentů učitelství 1. a 2. stupně vykazují pozoruhodně podobné výběrové zaměření pozornosti. Větší rozdíly pozorujeme jen v oblasti zaměření na žáka a učitele (viz obr. 1). Studenti jako celek si v hodině více všímají činnosti žáků a následně učitele, což je způsobeno výrazně vyšším důrazem studentů 1 . stupně na žáka. Studenti učitelství 2. stupně nejsou tak vyhranění a všímají si téměř stej-

Tab. 3. Výběrové zaměření pozornosti studentů obou stupňů

\begin{tabular}{|c|c|c|c|}
\hline & $\begin{array}{c}\text { Studenti učitelství } \\
\text { 1. stupně }\end{array}$ & $\begin{array}{c}\text { Studenti učitelství } \\
\text { 2. stupně }\end{array}$ & $\begin{array}{c}\text { Oba } \\
\text { stupně }\end{array}$ \\
\hline \multicolumn{4}{|l|}{ Aktér } \\
\hline učitel & $31 \%$ & $38 \%$ & $35 \%$ \\
\hline žák & $48 \%$ & $33 \%$ & $40 \%$ \\
\hline pozorovatel videa & $7 \%$ & $7 \%$ & $7 \%$ \\
\hline tvůrce kurikula & $9 \%$ & $13 \%$ & $11 \%$ \\
\hline jiné & $5 \%$ & $10 \%$ & $8 \%$ \\
\hline \multicolumn{4}{|l|}{ Téma } \\
\hline obor a jeho didaktika & $22 \%$ & $24 \%$ & $23 \%$ \\
\hline pedagogika a obecná didaktika & $42 \%$ & $48 \%$ & $45 \%$ \\
\hline klima tř́dy & $16 \%$ & $13 \%$ & $14 \%$ \\
\hline řízení třídy & $18 \%$ & $11 \%$ & $14 \%$ \\
\hline jiné & $3 \%$ & $4 \%$ & $4 \%$ \\
\hline \multicolumn{4}{|l|}{ Přístup } \\
\hline popis & $41 \%$ & $31 \%$ & $36 \%$ \\
\hline hodnocení & $46 \%$ & $49 \%$ & $47 \%$ \\
\hline interpretace & $11 \%$ & $18 \%$ & $15 \%$ \\
\hline jiné & $1 \%$ & $2 \%$ & $2 \%$ \\
\hline \multicolumn{4}{|l|}{ Míra konkrétnosti } \\
\hline konkrétní & $15 \%$ & $15 \%$ & $15 \%$ \\
\hline obecný & $85 \%$ & $85 \%$ & $85 \%$ \\
\hline
\end{tabular}




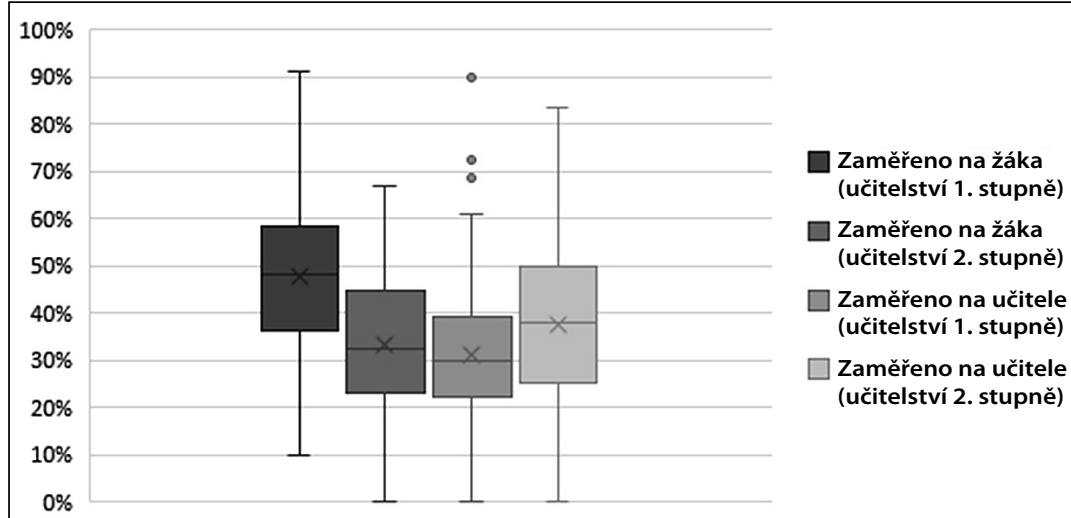

Obr. 1. Krabicové grafy pro rozdíly ve výběrovém zaměření pozornosti mezi studenty učitelství 1. a 2. stupně (vodorovná čára znamená medián, křížek aritmetický průměr, horní a dolní kvartil, lokální maximum a minimum, vyznačeny jsou odlehlé hodnoty vzdálené více než 1,5násobek kvartilového rozpětí)

nou měrou učitele i žáka. V oblasti Téma si studenti obou stupňů shodně výrazně nejvíce všímají pedagogických a obecně didaktických jevů na úkor jevů oborového a oborově didaktického charakteru a dalších aspektů hodiny.

To, čeho si všímají, studenti spíše jen popisují či subjektivně hodnotí, ale nevysvětlují ani neinterpretují s oporou o teorii. Př́ikladem je popisný výrok „Následovala samostatná práce s učebnicí ve dvojicích“ a hodnotící výrok „Líbilo se mi, že v této hodině měl každý svoji funkci ve skupině“. Studenti učitelství 1 . stupně více popisují než studenti druhé skupiny, a to na úkor interpretací. Studenti obou skupin se výrazně zabývají obecnými záležitostmi týkajícími se celé vyučovací hodiny či procesu výuky a málo komentují konkrétní události v hodině. To koresponduje s malým důrazem na oborové či oborově didaktické jevy, které jsou svou podstatou spíše specifického charakteru.

\subsection{Povaha interpretací, navrhování alternativ a predikce}

Většina jednotek kódovaných jako Interpretace (15\% z celkového počtu) obsahovala vysvětlení bez opory o teorii. U jednotek kódovaných Teoretizace šlo jen o $4 \%$ všech jednotek a u Alterací a Predikcí je toto číslo ještě menší ( $2 \%$, resp. $1 \%)$. Přesto se domníváme, že má smysl se zabývat jejich povahou, protože představují prekoncepty všímání si u studentů, s nimiž je možné ve vysokoškolské přípravě dále pracovat.

Výsledky analýz jsou shrnuty v tab. 4. Ač se jednalo o kvalitativní analýzu, uvádíme i četnosti jednotek prriřazených $\mathrm{k}$ jednot- 
livým kategoriím pro obě skupiny studentů, protože se mezi nimi ukázaly zajímavé rozdíly. Některé kategorie však jsou zastoupeny jen $\mathrm{v}$ malém počtu prípadů, abychom je mohly nějak interpretovat.

Studenti obou skupin se v podobné míre snažili interpretovat viděné $\mathrm{v}$ souvislosti s vyučovacími metodami a postupy, organizačními formami a pojetím výuky obecně. Relativně často si uvědomují, jak některé $\mathrm{z}$ nich mohou ovlivnit aktivní osvojování poznatků (např. „Dobré je i to, že gramatika není vyložena od učitele, pravidla vyvodí sami studenti.") či že je žádoucí partnerské pojetí výuky a možnost projevit názor („Žáci by měli být více považováni za spolutvůrce a partnery vyučování."). Studenti poukazují na důležitost tvořivosti (např. pro hodinu výtvarné výchovy: „Z videa na mě dýchala svoboda pohybu, slova a rozvoj vlastní tvůrčí osobnosti."), především $\mathrm{v}$ reflexích hodin vlastivědy a výtvarné výchovy, a na důležitost kooperativních aktivit pro rozvoj sociálních a komunikativních dovedností (zvl. u hodiny vlastivědy). Jako metody

Tab. 4. Teoretizace, Alterace a Predikce: absolutní a relativní četnosti jednotek

\begin{tabular}{|c|c|c|c|c|c|c|c|c|c|c|c|c|}
\hline & \multicolumn{4}{|c|}{ Teoretizace } & \multicolumn{4}{|c|}{ Alterace } & \multicolumn{4}{|c|}{ Predikce } \\
\hline $\begin{array}{l}\text { Podkategorie } \\
\text { / Stupeň }\end{array}$ & 1. & 2. & 1. & 2. & 1. & 2. & 1. & 2. & 1. & 2. & 1. & 2. \\
\hline $\begin{array}{l}\text { metody, formy, } \\
\text { postupy } \\
\text { a pojetí výuky }\end{array}$ & 50 & 37 & $26 \%$ & $24 \%$ & 6 & 38 & $13 \%$ & $46 \%$ & 5 & 0 & $14 \%$ & $0 \%$ \\
\hline $\begin{array}{l}\text { cíl výuky, } \\
\text { očekávané } \\
\text { výstupy, } \\
\text { kompetence, } \\
\text { obsah výuky }\end{array}$ & 41 & 37 & $21 \%$ & $24 \%$ & 5 & 14 & $11 \%$ & $17 \%$ & 19 & 28 & $54 \%$ & $67 \%$ \\
\hline $\begin{array}{l}\text { motivace, } \\
\text { aktivizace, } \\
\text { pozornost }\end{array}$ & 24 & 38 & $12 \%$ & $25 \%$ & 7 & 0 & $16 \%$ & $0 \%$ & 2 & 2 & $6 \%$ & $5 \%$ \\
\hline $\begin{array}{l}\text { řízení třídy } \\
\text { (management) }\end{array}$ & 9 & 0 & $5 \%$ & $0 \%$ & 13 & 8 & $29 \%$ & $10 \%$ & 0 & 0 & $0 \%$ & $0 \%$ \\
\hline $\begin{array}{l}\text { klima, vztahy } \\
\text { učitel-žák, } \\
\text { žák-žák }\end{array}$ & 18 & 22 & $9 \%$ & $14 \%$ & 0 & 0 & $0 \%$ & $0 \%$ & 0 & 7 & $0 \%$ & $17 \%$ \\
\hline $\begin{array}{l}\text { didaktické } \\
\text { zásady }\end{array}$ & 33 & 5 & $17 \%$ & $3 \%$ & 4 & 4 & $9 \%$ & $5 \%$ & 7 & 0 & $20 \%$ & $0 \%$ \\
\hline ostatní & 18 & 15 & $9 \%$ & $10 \%$ & 10 & 18 & $20 \%$ & $22 \%$ & 2 & 5 & $6 \%$ & $12 \%$ \\
\hline celkem & 193 & 154 & $100 \%$ & $100 \%$ & 45 & 82 & $100 \%$ & $100 \%$ & 35 & 42 & $100 \%$ & $100 \%$ \\
\hline
\end{tabular}


a postupy vedoucí $\mathrm{k}$ rozvoji oborových znalostí častěji uvádějí samostatnou práci žáků a postupy umožňující intelektuálně náročné zamýšlení se nad problémem, a to převážně u hodiny matematiky („Práce ve dvojici dobrá, ale myslím si, že by každé dítě mělo mít svou tabulku, aby si dotyčný tvořil sám a přemýšlel nad tím.").

Studenti obou skupin ve stejné míre teoreticky zdůvodňovali své postřehy týkající se vzdělávacích cílů, očekávaných výstupů, kompetencí či obsahu výuky. Obsahová analýza jejich výroků ukázala, že studenti učitelství 2 . stupně tak činili z hlediska oborových cílů a obsahu vzdělávání $\mathrm{v}$ rámci oborů, zatímco studenti učitelství 1. stupně z hlediska klíčových kompetencí či tzv. měkkých dovedností žáků („Práce tak plnila svůj účel, kdy se rozvíjela komunikace, poznávání druhých, spolupráce.“). Studenti 2. stupně poněkud více používali odborné pedagogické pojmy (induktivní způsob výuky, motivace, aktivizace apod.).

Zajímavý rozdíl se projevil v kategorii Motivace, Aktivizace a Pozornost. Studenti učitelství 2 . stupně více teoreticky zdůvodňovali její nutnost, zatímco studenti učitelství 1. stupně komentovali její nepř́itomnost a navrhovali u ní alterace. Ve zdůvodnění studentů obou skupin se objevují společné rysy: 1 . důležitost aktivizace žáků (např. „Obě tyto činnosti spolu $s$, matematickým kufrem 'žáky zcela evidentně měly aktivizovat a využít jejich soutěživého ducha pro účely lepšího proniknutí do předkládané látky."); 2. důležitost různorodých činností pro motivaci žáka („Paní učitelka střídala aktivity, což považuji jako dobré, aby se děti mohly soustředit a věnovat se zadané práci pořádně."); 3 . důležitost pochvaly a pozitivní motivace („Přišlo mi, že by mohla žáky $\mathrm{v}$ průběhu občas pochválit ... za dobrou myšlenku nebo za snahu a dát jim tak nějakou motivaci.").

Konečně studenti 2. stupně častěji zdůvodňovali vliv tř́dního klimatu na motivaci žáků a negativní úlohu stresu či soutěživosti na učení žáků; to mohlo být dáno i povahou hodiny, v níž se soutěž objevila. Studenti 1. stupně naopak častěji zmiňovali důležitost zájmu žáků o to, co se učí, a potřebu tento zájem u žáků vzbudit, důležitost sociální interakce a potřebu řízení učení žáků učitelem.

Naprííc kategoriemi z tab. 4 obsahová analýza ukázala, že studenti učitelství 1. stupně zdůrazňují význam kooperativních aktivit a vrstevnické pomoci, ale častěji jen okrajově, a to v souvislosti $s$ udržením pozornosti dětí („Děti jsou nuceny více se zamyslet nad tím, co napsali jejich spolužáci, a udrží to pozornost dětí více, než kdyby své nápady opět jenom prezentovaly."), ve vztahu k rozvoji obecných kompetencí („Vždycky to vysvětluje žák, což je dobré pro jeho slovní zásobu a vyjadřování, protože se to musí snažit vysvětlit spolužákům tak, aby to co nejlépe pochopili.") a ve významu dosažení různorodosti použivaných metod a forem práce a tím naplnění didaktické zásady přiměřenosti věku, respektive i individuálního př́stupu („Během dalších aktivit děti postupně musely pracovat ve dvojicích, jednotlivcích či skupinách, čímž se každému z nich alespoň na chvíli dostalo takového typu práce, který mu vyhovuje."). 
Jak je vidět z tab. 4, alteraci použitých vyučovacích metod, postupů práce, organizačních forem či pojetí výuky navrhují více studenti 2. stupně, a to především studenti reflektující hodinu matematiky (27 z celkového počtu 38 výroků; např. „Žák volící bod X3 udělal zajímavou chybu, o které se dalo diskutovat. Děti samy mohly chybu objevit."). Je to pravděpodobně způsobeno charakterem hodiny, kdy cílem učitele je, aby žáci objevili Thaletovu větu, ale činí tak př́iliš direktivně, nedává jim prostor pro aktivitu a málo je vede ke zdůvodňování. Studenti zde také navrhují alterace směrující $\mathrm{k}$ modifikaci role učitele ve výuce („Nejenom, že se nevyptá, proč si to tak myslí, a neobjasní mu, proč si to myslí nesprávně, ale také zamezí svou odpovědí tomu, aby se žák mohl zeptat, proč není jeho odpověd’ správná."). Rízení trí́dy bylo zdůrazňováno $s$ větší četností u studentů učitelství 1 . stupně, kteří navrhovali i více alternativ než studenti druhé skupiny (např. „Pomalejší žáci by ale podle mne na vstřebání úkolů a jejich problematiky potřebovali více času.").

Kategorie Predikce byla nejméně uváděnou kategorií ze všech zkoumaných (tab. 4). Nejčastěji studenti obou skupin predikují v oblasti vzdělávacích cílů a získání př́íslušných znalostí, dovedností či postojů. Studenti učitelství 2 . stupně výrazně více zaznamenávají predikci viděného na zapamatování učiva a získání oborových znalostí („Jako pozitivní hodnotím to, že žáci na pravidla přišli sami, což dle mého názoru vede $\mathrm{k}$ lepšímu zapamatování."). Studenti 1. stupně více zmiňují predikci viděného na rozvoj klíčových doved- ností či tzv. měkkých dovedností („Děti se naučí vzájemně si vysvětlit své názory..."). Studenti 1. stupně predikují v reflexi hodiny vlastivědy také vliv výuky na rozvoj postojů (což může souviset $s$ celkovým pojetím obsahu předmětu). Co se týče didaktických zásad, studenti učitelství 1. stupně predikují především význam uplatnění zásady uvědomělosti osvojovaných postupů.

\section{DisKuSE A ZÁVĚR}

\subsection{Výběrové zaměření pozornosti studentů a povaha viděného}

První výzkumná otázka se týkala zaměření pozornosti u studentů učitelství 1. a 2. stupně. Je obtížné naše výsledky porovnat $s$ jiným výzkumem, protože naši respondenti jsou na začátku svého oborového a oborově didaktického studia. Jak bylo uvedeno $\mathrm{v}$ úvodu, můžeme se opř́ít o výsledky studií, které zkoumají výběrové zaměření pozornosti u studentů učitelství před intervencí, která má vést $\mathrm{k}$ jeho rozvoji. Např́ílad Santagatová et al. (2007) ve výzkumu se studenty učitelství 2 . stupně potvrzují náś závěr pro studenty obou stupňů, že si více všímají obecných didaktických jevů na úkor obsahu a jeho výuky (v tomto prrípadě matematiky) a že jejich komentáre jsou spíše obecného charakteru. Ovšem liší se v tom, že zatímco naši studenti 2. stupně si všímají v hodině téměř stejně činnosti žḱků i učitele (stejně jako studenti ve studii Stockero et al., 2017), u jejich respondentů výrazně převažovaly komentáře o učiteli (podobně jako ve výzkumu Santagata \& Guarino, 2011; Mitchell \& Marin, 2015). 
V kvalitativně zaměřené studii (Mitchell \& Marin, 2015), které se účastnili pouze čtyři studenti, najdeme pozoruhodně shodné výsledky v oblasti všímání si oborových a pedagogických jevů i hodnocení a popisování viděného jako u naší skupiny studentů učitelství 2. stupně.

Jiné výsledky ovšem přináší výzkum Simpsona, Vondrové a Žalské (2017), provedený se studenty učitelství matematiky $\mathrm{v}$ jiném roce, ale ve stejném stadiu učitelské př́ípravy. Výsledky ve všech oblastech jsou podobné, až na oblast Téma, kde si studenti všímali více oborových jevů než jevů pedagogických, tedy opačně než $\mathrm{v}$ prezentovaném výzkumu (a to i tehdy, pokud se nebudeme dívat na výsledky všech skupin, ale jen skupiny MA2). Vzhledem $\mathrm{k}$ tomu, že $\mathrm{v}$ obou př́padech se jedná o vzorek na základě dostupnosti (a účastní se všichni studenti v ročníku), může být rozdíl dán rozdílnými vstupními dovednostmi studentů. Další možností je vliv zhlédnuté hodiny ( $\mathrm{v}$ obou studiích byly použity různé hodiny). To přináší otázku, jak moc jsou výsledky studií zaměřených na všímání si zobecnitelné.

$\mathrm{V}$ naší studii jsme zkoumali zaměrení pozornosti studentů učitelství 1 . i 2 . stupně jednotnou metodologií. Kromě studie Uličné (2017), která potvrzuje statistickou významnost rozdílného zaměření na žáka a učitele u skupin AJ1 a AJ2 účastnících se i našeho výzkumu, nám není znám výzkum, který by se zaměřoval na rozdíly v profesním vidění u obou skupin studentů. Můžeme tedy vycházet jen $\mathrm{z}$ dílčích studií, které zkoumají profesní vidění u učitelů 1 . stupně (či studentů učitelství 1. stupně) zvlášt́. Studenti učitelství 1 . stupně účastnící se naší studie si výrazně více všímali žáka než učitele. To bylo v souladu i s výsledky výzkumu, které zmiňuje Urbánek (2011) a které ukazují, že studenti učitelství 1. stupně jsou výrazně více orientováni na dítě. $V$ oblasti všímáni si podobné výsledky přináší i další studie (van Es \& Sherin, 2006; Sonmez $\&$ Hakverdi-Can, 2012), ovšem pro prvostupňové učitele $\mathrm{z}$ praxe. Vzhledem $\mathrm{k}$ charakteru výuky na 1 . stupni, kdy učitel tráví se svými žáky mnohem více času než učitel na 2. stupni a kdy je často obeznámen i s rodinným zázemím žáka a jeho individuálními potřebami, není tento fakt překvapivý. Zajímavé však je, že i studenti učitelství 1 . stupně obvykle bez učitelské zkušenosti si žáka všímají více než studenti druhé skupiny. Př́ícinu můžeme spatřovat v již zmíněné vysokoškolské př́ípravě, v níž absolvovali mj. osobnostně-sociální výcvik a předměty $\mathrm{z}$ ontogenetické psychologie. Dalším vysvětlením je možnost, že se na tento typ studia už hlásí uchazeči více zaměření na dítě než na obsah, jak naznačil i výzkum Blombergové et al. (2011) a přehledová studie Urbánka (2011).

Oproti tomu se nepotvrdilo, že studenti učitelství 2. stupně budou v souladu se svou větší orientací na obor (Urbánek, 2011) více komentovat oborové jevy. Důvod můžeme spatřovat $\mathrm{v}$ náročnosti oborově didaktického zpracování učiva a v komplexnosti procesů, které se v hodině odehrávají - pro studenty, kteří ještě nemají zkušenosti s vlastní výukou, může být obtižné všímat si oboru a toho, jak je látka konkrétně koncipována a učiteli v hodině vedena. Jejich pozornost 
zaujmou spiśe více viditelné jevy obecně pedagogického charakteru (např. Santagata et al., 2007; Michtell \& Marin, 2015; Stockero et al., 2017). Otázkou zůstává, zda by se očekávaný rozdíl $\mathrm{v}$ orientaci na obor projevil v př́padě, kdy by studenti nereflektovali celou vyučovací hodinu, ale jen její výsek (čímž se redukuje její komplexnost), nebo pokud by hodinu reflektovali zkušení učitelé obou stupňů škol.

Pokud si uvědomíme, že zkoumáme studenty na počátku jejich obecně i oborově didaktického vzdělávání, není jejich zaměření pozornosti $\mathrm{v}$ hodině a uvažování o viděném překvapivé. Ještě nemají znalosti, $v$ jejichž rámci by viděné reflektovali. Výsledky našeho výzkumu však můžeme považovat za důležitou informaci pro vzdělavatele učitelů. Pro studenty obou stupňů je obtížné si všímat žáka i učitele $\mathrm{z}$ pohledu rozvoje oborových poznatků. Mají tendenci viděné spíše subjektivně hodnotit, ale své hodnocení neopírají o to, co viděli v hodině, ani nevysvětlují. Kurzy oborových didaktik by se tedy měly zaměrit na ty části hodiny, kdy dochází $\mathrm{k}$ rozvoji poznatků, a měly by vést studenty $\mathrm{k}$ jejich rozboru. Oborově didaktická teorie by se měla úzce vázat na poznatky z praxe, třeba právě prostřednictvím analýz videí z hodin. Konečně, studenti by měli být vedeni $\mathrm{k}$ argumentaci a vysvětlování svých výroků o vyučování. Náš výzkum ukázal, že studenti tyto dovednosti ještě nemají.

\subsection{Povaha interpretací}

Většina jednotek, které šly za pouhou deskripci a subjektivní hodnocení, měly charakter laického vysvětlení bez opory o teorii. To není překvapivé, když uvážíme, že se jedná o studenty, kteří ještě neabsolvovali obecnou didaktiku ani didaktiky oborové. Teoretické zdůvodnění dokázali studenti obou stupňů poskytnout pro nejvíce viditelné jevy $\mathrm{v}$ hodině, tedy metody a formy výuky a cíl výuky a očekávané kompetence. Při tom kladou důraz na potřebu aktivního př́stupu $\mathrm{k}$ učení u žáka (což je v souladu se zjištěním Stehlíkové, 2010) a zdůvodňují např. důležitost různorodých činností žáka, pozitivní zpětné vazby a aktivizujících metod (ovšem spíše ve vazbě na rozvoj měkkých dovedností než oborových poznatků). U studentů učitelství 1 . stupně to lze vysvětlit jejich výše zmíněnou zkušeností z reflektivních seminárů, ale u obou skupin studentů se jistě projevuje i vliv dnešního paradigmatu výuky, v němž se právě aktivní role žáka a aktivizujících (někdy také chápaných jako herních) metod zdůrazňuje. Důrazu na aktivní roli žáka je možné $\mathrm{v}$ př́pravě učitelů využít, ovšem je nutné studenty vést tak, aby ho provazovali i na rozvíjení oborových znalostí žáka, nejen na měkké dovednosti a kompetence. Analýza videí doplněná výzvou, aby studenti zvažovali různé alternativy toho, co vidí $v$ hodině, a jejich možné důsledky pro rozvoj oborových poznatků se jeví jako dobrá cesta (Mitchell \& Marin, 2015; Sherin \& van Es, 2009).

Studenti velmi málo navrhovali alternativy (průměr na studenta byl 0,6 ), podobné zjištění najdeme pro budoucí učitele matematiky (Santagata \& Guarino, 2011, průměr na studenta 0,3$)$ či anglického jazyka (Minaříková, 2014). Studenti 
v našem výzkumu jen ojediněle predikovali možné následky pozorované výuky na budoucí znalosti (podobně Minaříková, 2014). Schopnost predikce považují někteří autoři (např. Stürmer, Könings \& Seidel, 2015) za nejvyšší úroveň dovednosti spojené s profesním viděním, a proto je pochopitelné, že na začátku studia není rozvinuta. Otázkou ovšem zůstává, nakolik ji lze v průběhu vzdělávání učitelů rozvíjet a jaké strategie k tomu volit. Stürmerová et al. $(2015,2016)$ jednak zjistili, že mezi studenty učitelství středoškolské matematiky a př́rodních věd jsou značné intra-individuální rozdíly jak u vstupních dovedností, tak v možnosti jejich dovednosti rozvíjet, a že zejména dovednost predikce je obtižněji ovlivnitelná a míra růstu dovedností studentů po intervenci klesá $s$ vyššími vstupními dovednostmi. Dovednost využít teorii pro interpretaci výuky a navrhnout $\mathrm{k}$ ní zdůvodněné alternativy patří mezi pokročilé dovednosti a $\mathrm{k}$ jejímu rozvoji má přispět vysokoškolská výuka. Jak bylo již zmíněno, naše výsledky mohou sloužit jako vstupní informace pro vzdělavatele učitelů $\mathrm{v}$ tomto ohledu.

\subsection{Omezení výzkumu a závěr}

Přestože počet analyzovaných jednotek byl značný (a v kontextu výzkumů profesního vidění spíše ojedinělý), při zobecňování výsledků je nutné mít na paměti, že výzkum byl proveden na omezeném vzor$\mathrm{ku}$, a sice u studentů učitelství při vstupu do učitelského studia převážně na jedné univerzitě $\mathrm{v}$ jednom akademickém roce. $\mathrm{Na}$ druhé straně byli do vzorku u šesti z devíti skupin zahrnuti všichni studenti v ročníku. Kvalitativní analýza měla za cíl hlubší vhled do zkoumané reality, ovšem získané poznatky nelze zobecňovat - jednak se týkají pouze vzorku, na kterém byly získány, a jednak lze polemizovat o tom, zda množství dat umožnilo odhalit všechny pravidelnosti, které se $\mathrm{v}$ nich mohou objevit (Švaříček \& Šed’ová, 2007).

Dalším limitem výzkumu je skutečnost, že byl zaměřen na výběrové zaměření pozornosti na základě zvoleného kategoriálního systému (i když široce využívaného), byl tedy orientován pouze na určité jevy, jiné mohly být opomenuty. Též nebyly zkoumány jiné formy výpovědí studentů (např. záznamy jejich společné diskuse), kde by se mohly některé parametry lišit v porovnání s písemnými výstupy. Stranou zůstaly i možné rozdíly $\mathrm{v}$ profesním vidění jednotlivých studentů.

Konečně je nutné vzít $v$ úvahu i charakter použitých videonahrávek, který ovlivnil výběrové zaměření pozornosti. Výzkumný tým vybíral videa autentické výuky z oboru, který studenti studovali, protože profesní vidění je považováno za schopnost, která závisí na konkrétním oborovém zaměrení zkoumané osoby (Steffensky et al., 2015). Videa byla zaměřena na získávání nových oborových poznatků a obsahovala řadu momentů vhodných pro komentování a interpretaci, nicméně nebylo možné zajistit, aby se ve všech videích objevovaly prvky stejné povahy (např. soutěž, práce ve skupinách) a ve stejné míre. Vlivem charakteru zhlédnutých hodin lze pak do značné míry vysvětlit i určité rozdíly mezi všímáním si jednotlivých jevů různými skupinami studentů. 
Grossmanová a Stodolsky (1995) hovoří o specifických (oborových) předmětových subkulturách $s$ vlastními přesvědčeními, normami a praktikami týkajícími se vyučování a učení. $V$ rámci naší studie jsme se pokusili zaměřit na vidění studentů, kteří do těchto subkultur vstupují. Věříme, že tento vhled může mít význam při uvažování o koncepci jejich vzdělávání.

Písemné reflexe se nám jeví jako vhodný nástroj pro zjištování oborově didaktických prekonceptů studentů na začátku učitelského studia. Jejich exaktní vyhodnocení není sice snadné, ale věríme, že náš pokus může přinést vyučujícím oborových didaktik i obecné didaktiky poměrně dobrý obrázek o znalostech, názorech a představách jejich studentů, z kterých pak mohou při plánování jejich vzdělávání vycházet. Znalost toho, čeho si všímají studenti, kteří jdou na praxi, může posloužit vedoucím praxí při zaměření pozornosti studentů na ty jevy hodiny, které, jak se ukázalo, opomíjejí.

$\mathrm{V}$ pokračování našeho výzkumu budeme sledovat posuny v profesním vidění stejné skupiny studentů po dvou letech studia obecné a oborové didaktiky. Bude zajímavé zjistit, do jaké míry jsou studenti schopni aplikovat teoretické poznatky z kurzů na analýzu výuky.

Výzkum byl podpořen programem Progres Q17 Príprava učitele a učitelská profese $v$ kontextu védy a výzkumu.

\section{Literatura}

Blomberg, G., Stürmer, K., \& Seidel, T. (2011). How pre-service teachers observe teaching on video: Effects of viewers and teaching subjects and the subject of the video. Teaching and Teacher Education, 27(7), 1131-1140.

Grossman, P. L., \& Stodolsky, S. S. (1995). Content as context: The role of school subjects in secondary school teaching. Educational Researcher, 24(8), 5-11.

Janík, T., Minaříková, E., Píšová, M., Uličná, K., \& Janík, M. (2016). Profesní viděni učitelů a jeho rozvijeni prostrednictvím videoklubi̊. Brno: Masarykova univerzita.

Janík, T., Minaříková, E., Píšová, M., Kostková, K., Janík, M., \& Hublová, G. (2014). Profesní vidění u učitelů: pokus o zmapování výzkumného pole. Pedagogika, 64(2), 151-176.

Kučera, M., et al. (1994). Pedagogická fakulta očima studentů. Výzkumná zpráva. Praha: SVI PedF UK.

Minaříková, E. (2014). Profesní vidění studentů učitelství anglického jazyka: jak vidí studenti výukové situace zachycené na videu? Pedagogická orientace, 24(5), 753-777.

Minaříková, E., \& Janík, T. (2012). Profesní vidění učitelů: od hledání pojmu k možnostem jeho uchopení. Pedagogická orientace, 22(2), 181-204.

Minaříková, E., Píšová, M., Janík, T., \& Uličná, K. (2015). Video clubs: EFL teachers' selective attention before and after. Orbis Scholae, 9(2), 55-75.

Mitchell, R. N., \& Marin, K. A. (2015). Examining the use of a structured analysis framework to support prospective teacher noticing. Journal of Mathematics Teacher Education, 18(6), 551-575. 
Santagata, R., \& Guarino, J. (2011). Using video to teach future teachers to learn from teaching. $Z D M, 43(1), 133-145$.

Santagata, R., Zannoni, C., \& Stigler, J. W. (2007). The role of lesson analysis in pre-service teacher education: an empirical investigation of teacher learning from a virtual video-based field experience. Journal of Mathematics Teacher Education, 10(2), 123-140.

Sherin, M., \& van Es, E. (2009). Effects of video club participation on teachers' professional vision. Journal of Teacher Education, 60(1), 20-37.

Simpson, A., Vondrová, N., \& Žalská, J. (2017). Sources of shifts in pre-service teachers' patterns of attention: the roles of teaching experience and of observational experience. Journal of Mathematics Teacher Education.

Sonmez, D., \& Hakverdi-Can, M. (2012). Videos as an instructional tool in pre-service science teacher education. Egitim Arastirmalari-Eurasian Journal of Educational Research, 12(46), 141-158.

Steffensky, M., Gold, B., Holdynski, M., \& Möller, K. (2015). Professional vision of classroom management and learning support in science classrooms: Does professional vision differ across general and content-specific classroom interactions? International Journal of Science and Mathematics Education, 13(2), 351-368.

Stehlíková, N. (2010). Interpretace některých didakticko-matematických jevů u studentů učitelství a učitelů matematiky. Pedagogika, 60(3-4), 303-313.

Stockero, S. L. (2008). Using a video-based curriculum to develop a reflective stance in prospective mathematics teachers. Journal of Mathematics Teacher Education, 11(5), 373-394.

Stockero, S. L., Rupnow, R. L., \& Pascoe, A. E. (2017). Learning to notice important student mathematical thinking in complex classroom interactions. Teaching and Teacher Education, 63, 384-395.

Stürmer, K., Könings, K. D., \& Seidel, T. (2015). Factors within university-based teacher education relating to preservice teachers' professional vision. Vocations and Learning, 8(1), $35-54$.

Stürmer, K., Seidel, T., \& Holzberger, D. (2016). Intra-individual differences in developing professional vision: preservice teachers' changes in the course of an innovative teacher education program. Instructional Science, 44(3), 293-309.

Straková, J., Spilková, V., Friedlaenderová, H., Hanzák, T., \& Simonová, J. (2014). Profesní přesvědčení učitelů základních škol a studentů fakult připravujících budoucí učitele. $P e-$ dagogika, 64(1), 34-65.

Strauss, A. L., \& Corbinová, J. (1999). Základy kvalitativního výzkumu: postupy a techniky metody zakotvené teorie. Brno: Sdružení Podané ruce.

Svatoš, T. (2013). A student teacher on the pathway to teaching profession: Reviewing research and proposing a model. Pedagogická orientace, 23(6), 786-809.

Syslová, Z. (2016). Rozvoj profesního vidění studentů oboru Učitelství pro mateřské školy. Pedagogika, 66(4), 462-476. 
Švaříček, R., \& Šed’ová, K. (2007). Kvalitativni výzkum v pedagogických vědách: pravidla hry. Praha: Portál.

Uličná, K. (2017). To see or not to see: Profesní vidění budoucích učitelů anglického jazyka a budoucích učitelů pro 1. stupeň se specializací na anglický jazyk. Pedagogická orientace, 27(1), 81-103.

Urbánek, P. (2011). Učitelské sbory základních škol: dvě odlišné profesní subkultury? In Walterová, E., et al. Dva světy základni školy? Úskali prěchodu z 1. na 2. stupeň (s. 269-294). Praha: Karolinum.

van Es, E. A., \& Sherin, M. G. (2006). How different video club designs support teachers in "learning to notice". Journal of Computing in Teacher Education, 22(4), 125-135.

Vondrová, N., \& Žalská, J. (2015). Ability to notice mathematics specific phenomena: What exactly do student teachers attend to? Orbis scholae, 9(2), 77-101.

RNDr. Lenka Pavlasová, Ph.D.

Katedra biologie a environmentálních studii, Pedagogická fakulta Univerzity Karlovy; e-mail: lenka.

pavlasova@pedf.cuni.cz

PhDr. Jana Stará, Ph.D.

Katedra preprimárni a primárni pedagogiky, Pedagogická fakulta Univerzity Karlovy

doc. RNDr. Nad'a Vondrová, Ph.D.

Katedra matematiky a didaktiky matematiky, Pedagogická fakulta Univerzity Karlovy

Mgr. Magdalena Novotná, Ph.D.

Katedra výtvarné výchovy, Pedagogická fakulta Univerzity Karlovy

doc. RNDr. Jarmila Robová, CSc.

Katedra didaktiky matematiky, Matematicko-fyzikálni fakulta Univerzity Karlovy

PhDr. Klára Uličná, Ph.D.

Katedra anglického jazyka a literatury, Pedagogická fakulta Univerzity Karlovy 


\title{
THE SELECTIVE DIRECTION OF ATTENTION IN STUDENTS OF TEACHING AND THE NATURE OF THEIR INTERPRETATIONS
}

\author{
Lenka Pavlasová, Jana Stará, Nad’a Vondrová, Magdaléna Novotná, Jarmila Robová, \\ Klára Uličná
}

Professional vision is an important link between professional knowledge and professional behaviour. This article presents the results of a study of the professional vision of students of teaching, some of them training for the second and third stage of Basic School and some for the first stage of Basic School (Primary School), and all just starting courses on general didactics and subject didactics. Analysing written responses $(n=211)$ to a video of a lesson, the researchers investigated the selective direction of attention and the extent to which and how students describe, rate and interpret the phenomena recorded in the video. The semantic units were coded using the Sharin and van Es category system (2009) and a modified version of the Stocker system (2008). Statements coded as theorisation, prediction and alteration were analysed qualitatively with the aim of identifying their nature. In the field of selective direction of attention the study confirmed some of the results obtained in students of maths teaching in preceding studies, but there were also differences. The students of 1st stage teaching devoted more attention to the pupil, while the comments of the students of 2nd and 3rd stage teaching were directed to pupil and teacher in equal measure. The students in both groups tended to comment more on general educational matters at the expense of subject issues and subject didactics and did very little in the way of interpretation (students of 1 st stage teaching even less than students in the second group) and their comments were very general. In their commentaries we can see an emphasis on the pupil's active approach to learning. The results of the study could contribute to innovation of the content of didactic disciplines in teaching training and the development of collaboration between specialists in different subject didactics.

Keywords: professional vision, noticing, teaching student, interpretation of what is perceived, teacher training. 